Original Research Paper

\title{
Long-Term Characterization of Landfill Leachate: Impacts of the Tropical Climate on its Composition
}

\author{
Jorge Luiz da Paixão Filho and Miriam Gonçalves Miguel \\ Faculty of Civil Engineering, Architecture and Urban Design, University of Campinas (Unicamp), Brazil
}

\author{
Article history \\ Received: 10-11-2016 \\ Revised: 18-01-2017 \\ Accepted: 08-03-2017 \\ Corresponding Author: \\ Jorge Luiz da Paixão Filho \\ Faculty of Civil Engineering, \\ Architecture and Urban \\ Design, University of \\ Campinas (Unicamp), Brazil \\ Email: jorgepaixao@gmail.com
}

\begin{abstract}
The disposal of Municipal Solid Waste (MSW) in sanitary landfills produces leachate, whose composition changes depending on the microbial community and the environmental conditions. However, these changes cannot be observed in sanitary landfill because of the superposition of cells, which makes it difficult to determinate the relationship among the phases of biodegradation of MSW, the composition of the leachate and the time required for complete stabilization of the waste. This illustrates the importance of building experimental cells that simulate landfill to monitor the leachate over a long period. This study aimed to analyze the composition of the leachate generated from an experimental cell built on the Delta A sanitary landfill of Campinas City, Brazil, over 945 days. The leachate showed a transition from an acidic anaerobic phase to a methanogenic phase within approximately 100 days. By the one-hundredth day, the leachate showed a characteristically low $\mathrm{pH}$, between 5.0 and 6.0 and a high Chemical Oxygen Demand (COD) and Biochemical Oxygen Demand (BOD) such as a young leachate with high biodegradability. Moreover, there was an intense leaching of the metals $\mathrm{Cd}, \mathrm{Fe}, \mathrm{Pb}$ and $\mathrm{Mn}$, with concentrations higher than those allowed for the release in water bodies, according to Brazilian law. After the one-hundredth day, the leachate was characterized as stabilized. The $\mathrm{pH}$ increased and the concentration of volatile fatty acid, $\mathrm{COD}$ and $\mathrm{BOD}$ decreased. $\mathrm{Co}, \mathrm{Zn}, \mathrm{Ni}$ and $\mathrm{Cu}$ were leached. The potentially toxic metal concentrations found in the leachate also were above the values allowed by Brazilian law.
\end{abstract}

Keywords: Metals, Sanitary Landfill, Monitoring, Biodegradation, Experimental Cell

\section{Introduction}

Brazil produces 259,547 t of Municipal Solid Waste (MSW) daily, with $167,636 \mathrm{t} \mathrm{day}^{-1}$ of these wastes disposed in sanitary landfills (IBGE, 2010). This disposal technique is commonly used throughout the world because of its low cost (Renou et al., 2008; Akgul et al., 2013). In recent years, the sanitary landfill has been implemented in Brazil more frequently. However, one of the disadvantages of this disposal technique is the production of leachate and biogas; depending on leachate composition, which is related to the state of biodegradation of the MSW disposed in the landfill, leachate treatment is fairly complex and costly (Kjeldsen et al., 2002).
The generation of leachate in landfills can cause a health risk and contaminate areas nearby so a detailed study of leachate composition is required to assess the waste disposal in landfills (Schiopu and Gavrilescu, 2010).

The variations in the leachate composition due to biodegradation of the MSW cannot be observed in sanitary landfill due to the superposition of cells that allows the mix of the leachate generated from wastes of different ages. This fact makes it difficult to establish the relationship among the phases of biodegradation of the MSW, the composition of the leachate and the time required for the complete stabilization of waste, i.e., methanogenic conditions (Kjeldsen et al., 2002).

In the landfill of Hong Kong, the variations in the leachate composition occurred in less than one year 
(Lo, 1996) and in the landfill of Taiwan, the time required was a year and a half (Chen, 1996). In the landfill of Wysieka, Poland, methanogenic conditions were established at the beginning of the monitoring period, which was 23 months (Kulikowska and Klimiuk, 2008). Therefore, the landfill operation conditions, the composition of the MSW and the regional climatic conditions may have favored such variations of the leachate at different times.

The leachate composition has a great influence on the choice of technology for its treatment. Biological treatment is simple and cost-effective (Renou et al., 2008). In the acidic leaching phase (BOD/COD $>0.5$ ), the "young landfill leachate" is amenable to biological treatment; however, the stabilized leachate contains recalcitrant compounds, which are difficult to degrade in biological processes (Cassano et al., 2011). In Brazil, the biological treatment, composed by anaerobic filter and facultative ponds, for a landfill leachate showed a decrease of COD removal efficiency from 87 to $35 \%$ after four years of operation of the sanitary landfill (Muller et al., 2015).

The use of Advanced Oxidation Processes (AOP) may be an alternative for treating the leachate of stabilized waste. However, optimum efficiency is achieved with a high oxidant dose, as demonstrated by Silva et al. (2004), which obtained $50 \%$ reduction of COD with a dose of ozone $3.0 \mathrm{~g} \mathrm{O}_{3} \mathrm{~L}^{-1}$. The use of AOP wet oxidation with different leachates, young and old, showed a high efficiency on COD removal at the young leachate (Oulego et al., 2016). The choice of treatment system of sanitary landfill leachate is important because can increase cost of disposal MSW. Therefore, it is essential to know the variations that occur in the leachate due to the biodegradation phases of the MSW.

Landfill leachate may include organic compounds such as benzene, toluene and phenol (Emenike et al., 2012; Aziz et al., 2010; Kulikowska and Klimiuk, 2008), mineral compounds such as $\mathrm{Ca}, \mathrm{Fe}, \mathrm{Mn}$ and $\mathrm{Mg}$ (Tatsi and Zouboulis, 2002) and Ag, As, Cd, Cr, Cu, Hg, $\mathrm{Ni}, \mathrm{Pb}$ and $\mathrm{Zn}$ (Mojiri et al., 2016; Gajski et al., 2012; Budi et al., 2016; Brennan et al., 2015; Amor et al., 2015; Hilles et al., 2015; Fauziah et al., 2013; Khattabi et al., 2002). Some of these metals are in a concentration higher than $1.0 \mathrm{mg} \mathrm{L}^{-1}$ (trace metals). The presence of metals in the leachate is concerning as it may persist in nature and can bioaccumulate in animals and humans (Fauziah et al., 2013).

The concentration of these compounds in the leachate depends on the type of landfill (industrial, sanitary or both) and on the waste biodegradation phase. Some studies have shown that landfill leachate present slow concentrations of heavy metals (Ehrig, 1983) and variations in these concentrations occur seasonally thus minimizing their impact (Tsarpali et al., 2012).
However, high concentrations of heavy metals have been observed in leachate in some studies. The $\mathrm{Pb}$ concentrations in the leachates from two landfills of different ages in China, one with 5 years and another landfill with 20 years of operation, were 11.39 and 4.56 $\mathrm{mg} \mathrm{L}^{-1}$, respectively; and in both cases, the $\mathrm{pH}$ value of the leachates was above 7.0 (Zhang et al., 2013).

Gajski et al. (2012) observed that the concentration of $\mathrm{Hg}$ and $\mathrm{Fe}$ in two leachate samples from Roving sanitary landfill, Croatia, was above the allowed for discharge into the environment. The $\mathrm{Hg}$ concentrations were 0.029 and $0.041 \mathrm{mg} \mathrm{L}^{-1}$ and the limit is $0.01 \mathrm{mg}$ $\mathrm{L}^{-1}$. These two leachate samples from Roving, Croatia showed genotoxicity and may create a risk to human health (Gajski et al., 2012).

In Brazil, the variations in the concentration of metals have also been studied and the values have been above those allowed by environmental legislation. CONAMA 430 (Brasil, 2011) allow being released into a water body 1.0 and $15.0 \mathrm{mg} \mathrm{L}^{-1}$, respectively, of $\mathrm{Mn}$ and $\mathrm{Fe}$. In the landfill of Santa Catarina, high concentrations of Mn and Fe, 20.17 and $62.8 \mathrm{mg} \mathrm{L}^{-1}$, respectively, have been observed (Bortolotto et al., 2009). The concentrations of Fe and Mn are usually low in the methanogenic phase (Kjeldsen et al., 2002), different from the observed in previous research

In the sanitary landfills under tropical conditions, i.e., high rainfall and temperature, the MSW biodegradation process is accelerated and, consequently, the leachate composition presents peculiar characteristics. Considering this fact and the influence of the superposition of cells in the leachate composition, the aim of this study was to evaluate the composition of leachate generated in an isolated experimental cell installed at the Municipal Sanitary Landfill Delta A, located in Campinas city, State of São Paulo, Brazil, over 945 days (about 2 years and 7 months). To assess the possible environmental impact of the landfill, the leachate composition was compared with the environmental legislation requirements.

\section{Material and Methods}

The city of Campinas is situated in São Paulo state, Brazil and has approximately 1,154,617 inhabitants in an area of $794,433 \mathrm{~km}^{2}$. Campinas is the third most populous municipality of the state and the fourteenth most populous in the country. The city is the thirteenth richest city in Brazil based on Gross Domestic Product (GDP) (IBGE, 2014).

The climate of Campinas is tropical (type CWA, according to Koppen), with dry and mild winters. Summers are rainy, with moderately high temperatures. The average annual rainfall is $1,350 \mathrm{~mm}$, with the month of January being the wettest and August being the driest (Wikipedia, 2015). 
All of the MSW generated in Campinas, approximately 1,000 t.day ${ }^{-1}$, was disposed at the Delta A municipal sanitary landfill until 2014. An MSW experimental cell was built at an altitude of $630 \mathrm{~m}$, atop the massive landfill and filled on time of 20 days. This experimental cell has an area of $5,080 \mathrm{~m}^{2}$ and a total volumetric capacity of approximately $15,000 \mathrm{~m}^{3}$ and has all of the constituents of a sanitary landfill: A liner system composed of compacted soil, geomembrane and geotextile; drainage systems for gas and leachate; cover system and geotechnical monitoring using piezometers, settlement plates and surface landmarks.

The drainage system was composed by a $0.3 \mathrm{~m}$ thick gravel layer and a central channel $30.0 \mathrm{~cm}$ deep and 2.0 $\mathrm{m}$ wide; therefore, the leachate generated in the cell flowed into an external box, where it was possible to measure the leachate flow and collect samples for physicochemical analyses. Further information about the experimental cell implementation is available in Benatti et al. (2013).

To fill the experimental cell, only the MSW from daytime collection from the city of Campinas was used. Twenty-seven characterization tests were performed on the MSW of Campinas in the filling time of the cell (Miguel et al., 2016). The characterization was performed according to the per capita income of the area of the city. The leachate produced was characterized for 945 days (about 2 years and 7 months).

The parameters used in the characterization of the leachate were: Chemical Oxygen Demand (COD) (Method 5220 D, Colorimetric Method), Biochemical Oxygen Demand (BOD) (Method 5210 B. 5-Day BOD Test), Ammonia Nitrogen (AN) (Method 4500 B and C, distillation and titrimetric), Electrical Conductivity (EC) (Method 2510 B) and $\mathrm{pH}$ (Method 4500-H+ A), according to APHA (1998). In addition, the presence of inorganic compounds ( $\mathrm{Fe}, \mathrm{Ca}, \mathrm{Cd}, \mathrm{Pb}, \mathrm{Mg}, \mathrm{Si}, \mathrm{Cu}$ and $\mathrm{Mn})$ was analyzed by Inductively Coupled Plasma Optical Emission Spectrometry (ICP-OES) (Method 3010B, 3030G, 3125B). The VFA was determined as described by Dilallo and Albertson (1961). The total alkalinity was determined according to the method described by Ripley et al. (1986). The leachate samples were not filtered in any of the experimental steps.

The monitoring of the characteristics of the leachate was divided into two stages: (a) Stage 1 spanned from the completion of cell filling (day 0) to monitoring day one hundred (day 100): (b) Stage 2 spanned day 101 to day 945. The monitoring was performed weekly for the first 420 days; from day 420 to 546 it was performed twice per month and from then on, it was performed monthly.

\section{Results and Discussion}

The monthly precipitation values for the years 2012, 2013 and 2014 are presented in Fig. 1. The total annual precipitation values for 2012, 2013 and 2014 were: $1,589 \mathrm{~mm}, 1,109$ and $921 \mathrm{~mm}$, respectively. A reduction in precipitation has occurred over the years. The precipitation in 2012 was above the historical average. However, the years 2013 and 2014 presented less than average annual precipitation. According to Khattabi et al. (2002), the leachate composition is influenced by temperature and precipitation.

The $\mathrm{pH}$ and Electrical Conductivity (EC) of the leachate from the experimental cell are shown in Fig. 2. In Stage 1, the $\mathrm{pH}$ values were low, between 4.5 and 6.0. These low $\mathrm{pH}$ values are related to the high concentration of Volatile Fatty Acids (VFA) in the leachate (Fig. 3). The high concentration of VFA $\left(>10,000 \mathrm{mg} \mathrm{HAc} \mathrm{L}^{-1}\right)$ is an indication that the MSW is in the acid phase of anaerobic biodegradation (Johansen and Carlson, 1976). In Stage 2, the pH increases, reaching values higher than 7.0. Concurrently with the increase of $\mathrm{pH}$, there was a reduction in the concentration of VFA (Fig. 3). Because the filling of the experimental cell was performed for 20 days, it was not possible to observe the aerobic phase of waste degradation. According to Kjeldsen et al. (2002), the aerobic phase spans a few days.

The highest values for EC were found in Stage 1 (Fig. 2). Landfill leachate typically presents a high EC values because of the large amount of dissolved materials. In Stage 1, the highest EC value was 56.6 $\mathrm{mS} \mathrm{cm} \mathrm{cm}^{-1}$, at 86 days of operation. Khattabi et al. (2002) found a high electrical conductivity in leachate from Etueffont landfill, Belfort France, influenced mainly by chloride, bicarbonate and cations. High concentrations of chloride and sodium ions in the leachate can inhibit biological anaerobic treatment (Kawai et al., 2012).

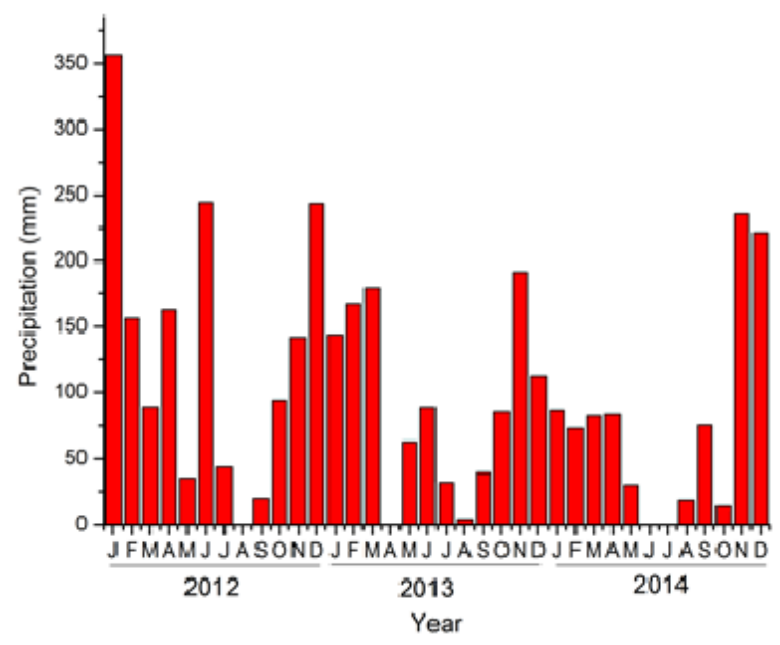

Fig. 1. Total monthly precipitation in Delta A landfill 


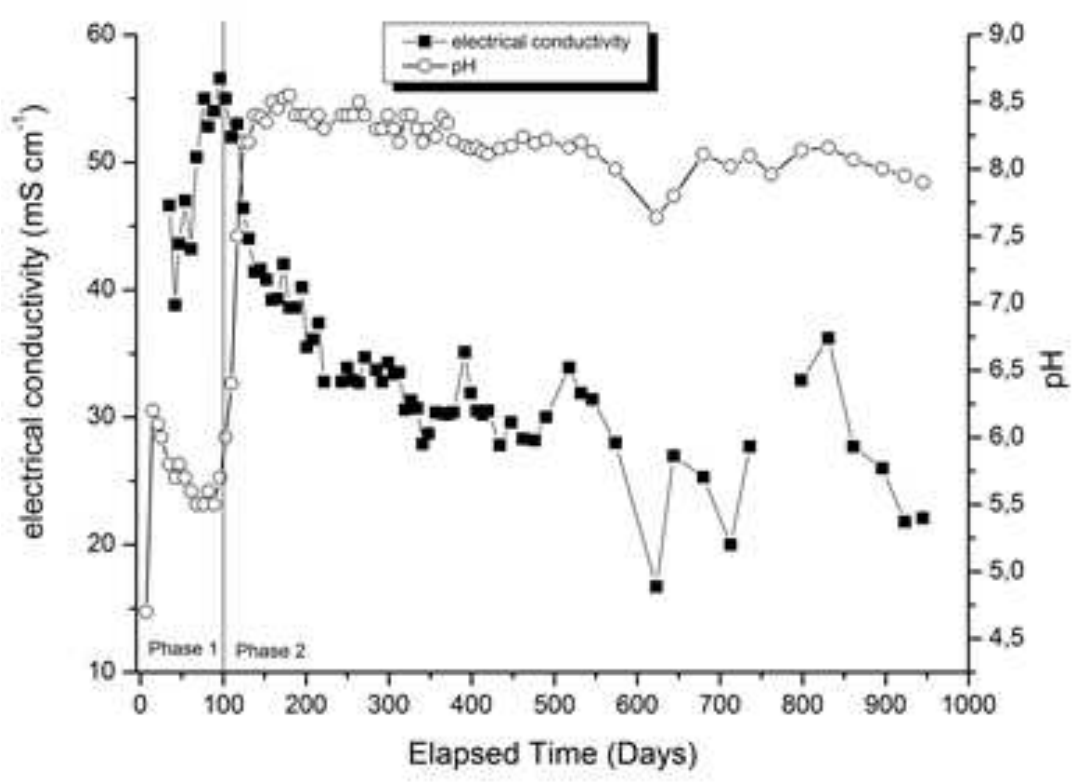

Fig. 2. Electrical conductivity and $\mathrm{pH}$ parameters in the leachate of the experimental cell

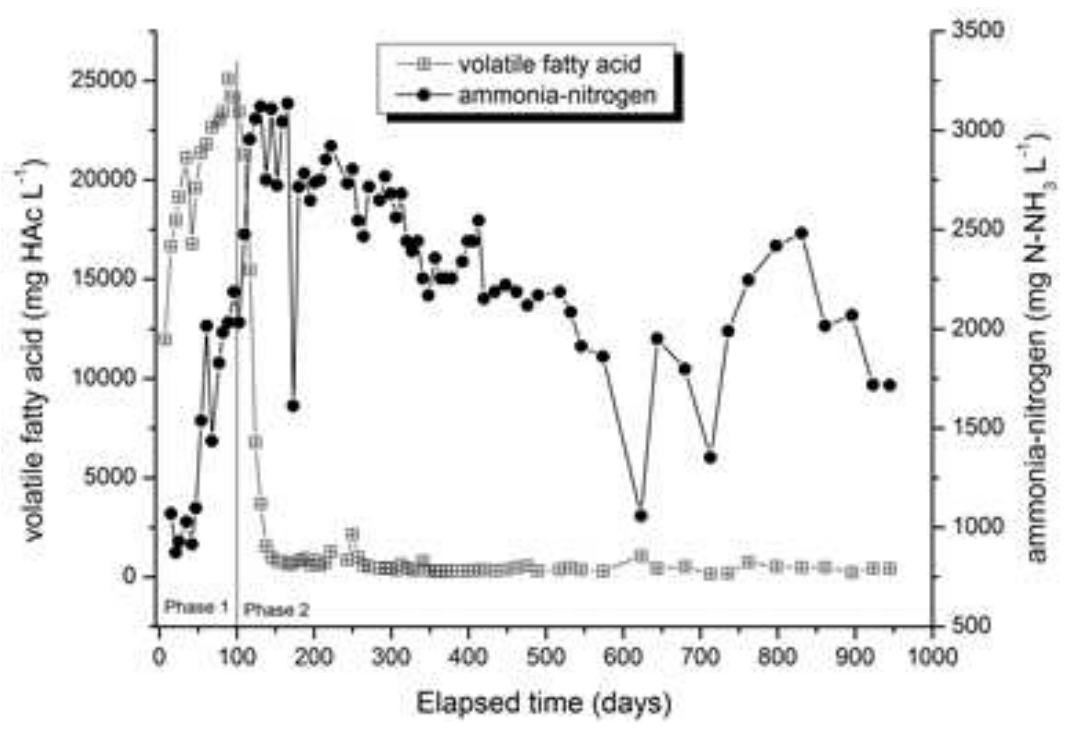

Fig. 3. Concentration of volatile fatty acids and ammonia nitrogen in the leachate of the experimental cell

The analysis of the leachate from a landfill in Taiwan showed that the EC decreases with increasing age of the landfill (Fan et al., 2006). The EC of the leachate from experimental cell in Stage 1 was above the range of values found to leachate from landfills: $2.5-35.0 \mathrm{mS}$ $\mathrm{cm}^{-1}$ (Kjeldsen et al., 2002).

According to Johansen and Carlson (1976), the cations calcium, magnesium, sodium and potassium help to increase the electrical conductivity. The concentration of these cations in the leachate was high in Stage 1. The concentrations of $\mathrm{Ca}$ and $\mathrm{Mg}$ in this period were 15,740 and $2,495 \mathrm{mg} \mathrm{L}^{-1}$, respectively (Fig. 6 and 7). Fan et al. (2006) observed that there were greater concentrations of $\mathrm{Ca}, \mathrm{Mg}, \mathrm{Na}$ and $\mathrm{K}$ among the 13 metals analyzed in the leachate of three landfills in Taiwan. In a landfill in Rio de Janeiro, southeastern Brazil, the concentrations of $\mathrm{Na}, \mathrm{K}, \mathrm{Ca}$ and $\mathrm{Mg}$ were 22,770, 3,200, 1,700 and 1,900 $\mathrm{mg} \mathrm{L}^{-1}$, respectively (Silva et al., 2004).

The concentration of VFA underwent a major change over the monitoring period. In Stage 1, the concentration of VFA reached 25,000 mg Hac L ${ }^{-1}$ (Fig. 3). In Stage 2, 
a decline in this value was observed, possibly caused by consumption of these compounds by methanogenic bacteria, because the environment (with a $\mathrm{pH}$ of approximately 7.0) was suitable for the growth of these bacteria (Ehrig, 1983). A VFA/alkalinity ratio of less than 0.8 is a requirement for the development of methanogenic bacteria and thus the production of methane (Ehrig, 1983). In Stage 1, this ratio showed values higher than 1.0 in the experimental cell and the Stage 2 values were less than 0.4 , suggesting the possible establishment of the methanogenic phase.

Ammonia nitrogen and organic matter are the compounds of concern in leachate (Kulikowska and Klimiuk, 2008). The Ammonia Nitrogen (AN) concentration in the leachate from the experimental ranged from 873.0 to $3,225 \mathrm{mg} \mathrm{L}^{-1}$ (Fig. 3). The AN concentration increased until the end of Stage 1 (Fig. 3). According to Ehrig (1983), parameters such as AN may increase slightly over the period of operation of the landfill. However, in Stage 2, the AN concentration showed a downward trend, in contrast to the findings of Kulikowska and Klimiuk (2008; Castrillón et al., 2010). In other studies, an ammonia nitrogen concentration ranging from 500.0 to $2,000 \mathrm{mg} \mathrm{L}^{-1}$ has been reported (Kjeldsen et al., 2002). Besides, high concentration of $\mathrm{AN}$ in the leachate can cause a decrease in nitrification in co-treatment in municipal wastewater treatment plant (Brennan et al., 2017).

The total alkalinity exhibited an increasing trend in Stage 1 , with a maximum value of $21,883 \mathrm{mg} \mathrm{CaCO}_{3} \mathrm{~L}^{-1}$ near the end of Stage 1 (Fig. 4). Rafizul and Alamgir (2012) also observed an elevated alkalinity (10,000 mg $\mathrm{CaCO}_{3} \mathrm{~L}^{-1}$ ) in the initial stage of degradation of MSW, with a decrease over time in experiments with lysimeters. In Stage 2, there was a trend toward a reduction in alkalinity over time.

The Redox Potential (RP) of the leachate from the experimental cell widely varied over the monitoring period (Fig. 4). In Stage 1, there was a decrease in RP. According to Qasin and Chiang (1994), a decrease in $\mathrm{RP}$ reflects a change in the degree of waste stabilization, i.e., the decrease could indicate transformation from the anaerobic acid phase to the initial methanogenic phase.

The Biochemical Oxygen Demand (BOD) showed values greater than $25,000 \mathrm{mg} \mathrm{O}_{2} \mathrm{~L}^{-1}$ in Stage 1 (Fig. 5). This observation corroborates the findings of the various researchers who claimed that the young leachate has a higher biodegradability and is amenable to biological treatment. The observed values for this first phase are within the range of the leachate anaerobic acid phase: 4,000 to $40,000 \mathrm{mg} \mathrm{L}^{-1}$ (Ehrig, 1989). At the beginning of Stage 2, the BOD values started to decrease,

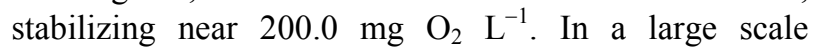

lysimeter $\left(3,000 \mathrm{~m}^{2}\right)$ in Shanghai the highest BOD was approximately $16,000 \mathrm{mg} \mathrm{L}^{-1}$, between 50.0 and 100.0 days of refuse age and after the BOD concentration decreased for approximately $2,000 \mathrm{mg} \mathrm{L}^{-1}$ until 350.0 refuse age (Youcai et al., 2002).

The Chemical Oxygen Demand (COD) was higher than $50,000 \mathrm{mg} \mathrm{O}_{2} \mathrm{~L}^{-1}$ in Stage 1 (Fig. 5). In the anaerobic acid biodegradation phase of the MSW, the COD can range between 6,000 and $60,000 \mathrm{mg} \mathrm{L}^{-1} \mathrm{O}_{2}$ (Ehrig, 1989). The highest COD was 77,924 $\mathrm{mg} \mathrm{O}_{2} \mathrm{~L}^{-1}$ on the sixty-eighth day of monitoring. The highest COD in the landfill leachate from Asturia, Spain, was 80,000 $\mathrm{mg} \mathrm{O}_{2} \mathrm{~L}^{-1}$ in the first year of operation (Castrillón et al., 2010). This high COD in Stage 1 can be correlated with the presence of easily biodegradable Organic Matter $(\mathrm{OM})$ in the MSW of the city of Campinas, which approximately 43\% of OM (Miguel et al., 2016). Brennan et al. (2015) observed COD variation of 411 to $7,160 \mathrm{mg} \mathrm{L}^{-1}$ in the leachate composition in Ireland. This variation is lower than that observed in the experimental cell, because in the European Union (EU), the organic wastes, which are sent to sanitary landfills, were reduced.

In Stage 1, the BOD/COD ratio was 0.6 , showing high biodegradability. However, for Stage 2, this ratio was low, between 0.1 and 0.2 . This fact indicates that in tropical regions the MSW biodegradation process is accelerated, reaching the stabilization in shorter time than indicated by the classic techno-scientific literature i.e., 2 to 5 years. However, the shorter time were also found in Hong Kong (Lo, 1996), Taiwan (Chen, 1996), Poland (Kulikowska and Klimiuk, 2008). This early transition from the acid anaerobic phase to the methanogenic phase interferes with the choice of the leachate treatment process. In the treatment of leachate in wastewater treatment plant, studied by Brennan et al. (2017), the performance of biological reactors was better with old leachate when compared to the new leachate.

The COD is a simple parameter that indicates the presence of organic matter in leachate. However, the presence of inorganic compounds, such as Fe (II), may result in overestimation of the obtained values (Kylefors et al., 2003). In stage 1, iron had a higher concentration (Fig. 6) than the Maximum Allowed Value (MAV) to be released into water bodies, according to CONAMA 430 (Brasil, 2011) (Table 1). There was intense leaching of iron in the experimental cell, when the $\mathrm{pH}$ was lower, during Stage 1 (Fig. 2). With increasing $\mathrm{pH}$, the $\mathrm{Fe}$ concentration decreased. The leachate from sanitary landfill of the Algiers city presented high concentrations of $\mathrm{Fe}\left(21.5 \mathrm{mg} \mathrm{L}^{-1}\right)$ and $\mathrm{Cd}\left(1.70 \mathrm{mg} \mathrm{L} \mathrm{L}^{-1}\right)$ when the $\mathrm{pH}$ was above of 8.0 (Boumechhour et al., 2013). The high concentration of Fe was $486.4 \mathrm{mg} \mathrm{L}^{-1}$ in Stage 1 (Table 2). 


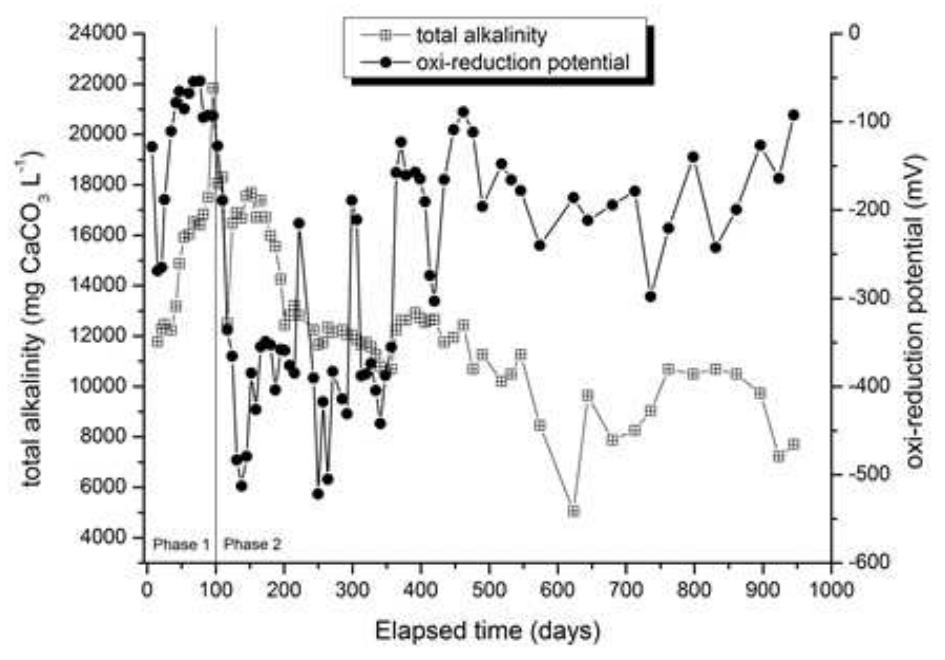

Fig. 4. Total alkalinity concentration and redox potential in the leachate of the experimental cell

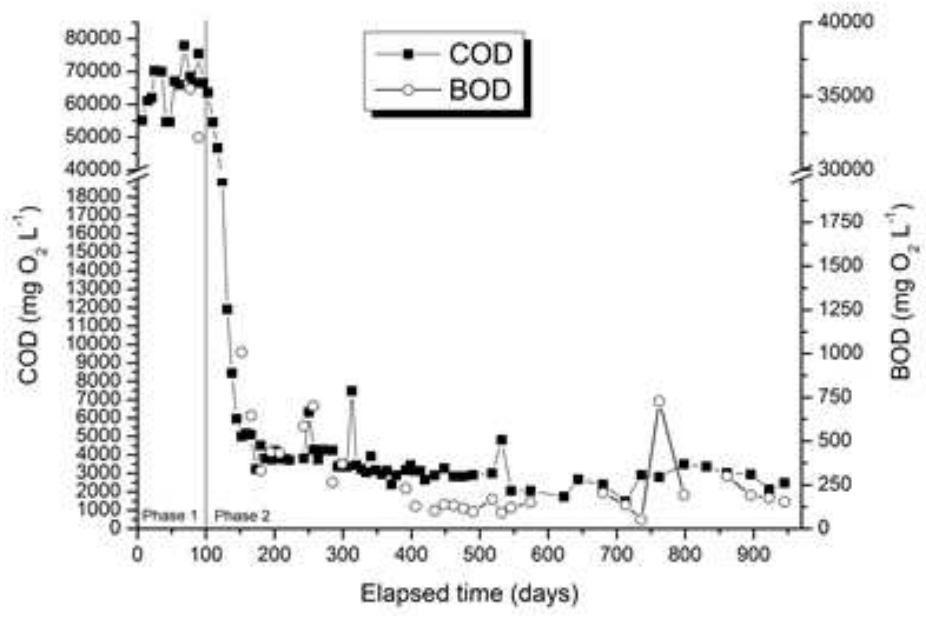

Fig. 5. Chemical oxygen demand and biochemical oxygen demand in the leachate of the experimental cell

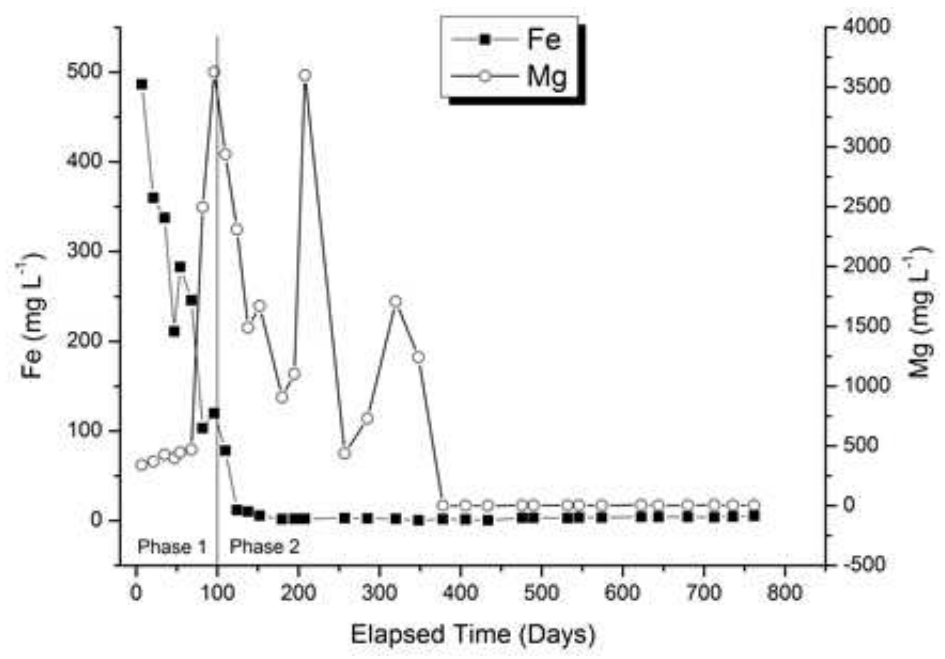

Fig. 6. Fe and $\mathrm{Mg}$ concentration in the leachate of the experimental cell 


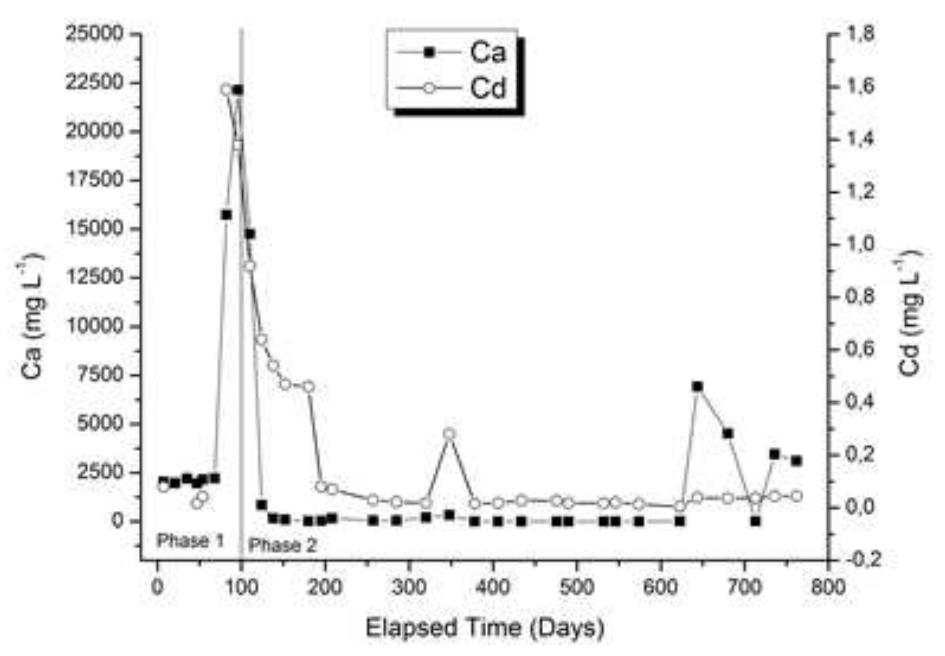

Fig. 7. $\mathrm{Ca}$ and $\mathrm{Cd}$ concentration in the leachate of experimental cell

Table 1. Parameters for effluent discharges (Brazil, 2011)

\begin{tabular}{ll}
\hline Inorganic Parameters & Maximum values \\
\hline Total cadmium & $0.2 \mathrm{mg} \mathrm{L}^{-1} \mathrm{Cd}$ \\
Total Lead & $0.5 \mathrm{mg} \mathrm{L}^{-1} \mathrm{~Pb}$ \\
Dissolved copper & $1.0 \mathrm{mg} \mathrm{L}^{-1} \mathrm{Cu}$ \\
Dissolved Iron & $15.0 \mathrm{mg} \mathrm{L}^{-1} \mathrm{Fe}$ \\
Dissolved Manganese & $1.0 \mathrm{mg} \mathrm{L}^{-1} \mathrm{Mn}$ \\
Total nickel & $2.0 \mathrm{mg} \mathrm{L}^{-1} \mathrm{Ni}$ \\
Total zinc & $5.0 \mathrm{mg} \mathrm{L}^{-1} \mathrm{Zn}$ \\
\hline
\end{tabular}

Table 2. Maximum and minimum concentration of metal in leachate of the experimental cell

\begin{tabular}{lll}
\hline & $\mathrm{mg} \mathrm{L}^{-1}$ & \\
Parameter & Minimum & Maximum \\
\hline $\mathrm{Fe}$ & 0.207 & 486.4 \\
$\mathrm{Mg}$ & 0.05 & $3,627.0$ \\
$\mathrm{Ca}$ & 0.04 & $22,150.0$ \\
$\mathrm{Cd}$ & 0.005 & 1.59 \\
$\mathrm{Cu}$ & 0.04 & 1.05 \\
$\mathrm{Ni}$ & $0.0 *$ & 8.7 \\
$\mathrm{Co}$ & 0.01 & 6.06 \\
$\mathrm{Al}$ & 0.08 & 1.03 \\
$\mathrm{Zn}$ & 0.16 & 6.55 \\
$\mathrm{Mn}$ & 0.02 & 24.84 \\
$\mathrm{~Pb}$ & 0.03 & 87.7 \\
\hline
\end{tabular}

* LLOQ - Less limit of quantitation

The $\mathrm{Mg}$ concentration was high in Stage 1 and up to day 350 in Stage 2 (Fig. 6). The high concentrations of $\mathrm{Mg}$ were $3,627 \mathrm{mg} \mathrm{L}^{-1}$ in the end Stage 1 (Table 2). This fact should facilitate the use of the ammonia removal process by chemical precipitation in the form of struvite $\left(\mathrm{MgNH}_{4} \mathrm{PO}_{4}\right)$. Kochany and Lipzynska-Kochany (2009) achieved a $36 \% \mathrm{~N}^{-\mathrm{NH}_{3}}$ removal of landfill leachate with high concentration of $\mathrm{Mg}\left(172 \mathrm{mg} \mathrm{L}^{-1}\right)$, only with aeration and addition of $\mathrm{H}_{3} \mathrm{PO}_{4}$ (phosphoric acid).
The inorganic compounds with higher concentrations in the leachate from the experimental cell were $\mathrm{Ca}, \mathrm{Mg}$ and $\mathrm{Fe}$. The $\mathrm{Ca}$ concentration was higher in Stage 1, when the $\mathrm{pH}$ was acidic (Fig. 7). The highest concentration of $\mathrm{Ca}$ in the leachate from the experimental cell was $22,100 \mathrm{mg} \mathrm{L}^{-1}$. Calcium is usually the cation that is present at higher concentrations in landfill leachate (Ehrig, 1983), as corroborated by the data observed in this study (Fig. 7). The high calcium concentration in the leachate can be connected to the presence of construction materials, such as gypsum and cement, in MSW.

The concentration of $\mathrm{Cd}$ in the leachate from the experimental cell was higher than MAV under Brazilian law (Table 1) in seven tests. This high concentration of Cd was observed in the transition from Stage 1 to Stage 2 with a concentration $1.59 \mathrm{mg} \mathrm{L}^{-1}$ (Table 2). In the leachate from Ouled Fayet landfill (Algiers) the $\mathrm{Cd}$ concentration was $1.70 \mathrm{mg} \mathrm{L}^{-1}$, above the maximum value allowed in Algiers (Boumechhour et al., 2013). In the leachate from a sanitary Isfahan, Teran, the concentration of $\mathrm{Cd}$ and $\mathrm{Ni}$ was higher, 2.5 e $4.6 \mathrm{mg} \mathrm{L}^{-1}$, respectively (Mojiri et al., 2016). In unfiltered sample of leachate of Ettueffont landfill the nickel concentration has a range 0.17 to $8.64 \mathrm{mg} \mathrm{L}^{-1}$ with average $2.08 \pm 2.68$ $\mathrm{mg} \mathrm{L}^{-1}$ (Khattabi et al., 2002).

The concentrations of $\mathrm{Ni}$ and $\mathrm{Cu}$ were high in Stage 2, where the $\mathrm{pH}$ was above 7.0 (Fig. 8). The highest concentration of $\mathrm{Ni}$ and $\mathrm{Cu}$ were 8.7 and $1.05 \mathrm{mg} \mathrm{L}^{-1}$ respectively (Table 2). The concentration of $\mathrm{Ni}$ was above the MAV under Brazilian law (Table 1) four times and $\mathrm{Cu}$ concentration twice (Fig. 8). According to Jarup (2003) $\mathrm{Cd}$ and $\mathrm{Ni}$ are used in batteries and rechargeable batteries and are often discarded in household waste. The nickel concentration was $4.63 \mathrm{mg} \mathrm{L}^{-1}$ and $\mathrm{pH}$ was between 7.9 and 8.4 in leachate from Deir El-Balah 
Landfill Site, Palestine (Hilles et al., 2015). It is very important to have a project to recover batteries with $\mathrm{Cd}$ and $\mathrm{Ni}$ in Brazil.

In the evaluation of the metals using two lysimeters, with and without recirculation of leachate, $\mathrm{Ni}$ concentrations of $4.5 \mathrm{mg} \mathrm{L}^{-1}$ and $6.7 \mathrm{mg} \mathrm{L}^{-1}$, respectively, were observed at the beginning of the experiments. After 400 days of monitoring, the concentrations were reduced to close to $2.0 \mathrm{mg} \mathrm{L}^{-1}$ in both lysimeters (Bilgini et al., 2007). Zinc (Zn) also presented values above MAV in Stage 2 (Fig. 9). The $\mathrm{Zn}$ concentration in the experimental cell leachate was much lower than that in three other landfills at different ages in China. Zhang et al. (2013) found for the landfills $\mathrm{X}, \mathrm{S}$ and $\mathrm{N}$ that the concentrations of $\mathrm{Zn}$ were $17.21,532.5$ and $1,331.25 \mathrm{mg} \mathrm{L}^{-1}$, respectively. In a young leachate $(\mathrm{BOD} / \mathrm{COD}=0.5)$ from a sanitary landfill, the concentrations of $\mathrm{Zn}, \mathrm{Cr}$ and $\mathrm{Fe}$ were 827 $\mathrm{mg} \mathrm{L}^{-1}, 25.7 \mathrm{mg} \mathrm{L}^{-1}$ and $97.7 \mathrm{mg} \mathrm{L}^{-1}$ respectively (Fauziah et al., 2013). Cobalt (Co) showed an intense leaching in the methanogenic phase (Fig. 9).

The presence of heavy metals in leachate is a concern because it may inhibit biological treatment. In aerobic reactors, a reduction of the nitrification process can occur and in anaerobic reactors can reduce the methanogenic activity.

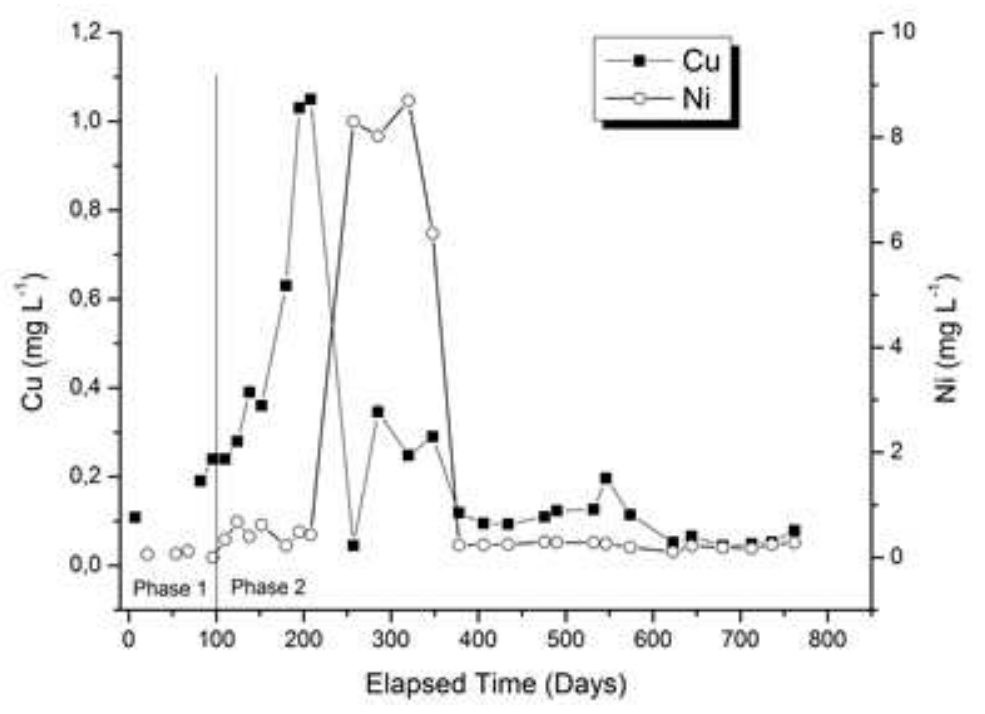

Fig. 8. $\mathrm{Cu}$ and $\mathrm{Ni}$ concentration in the leachate of the experimental cell

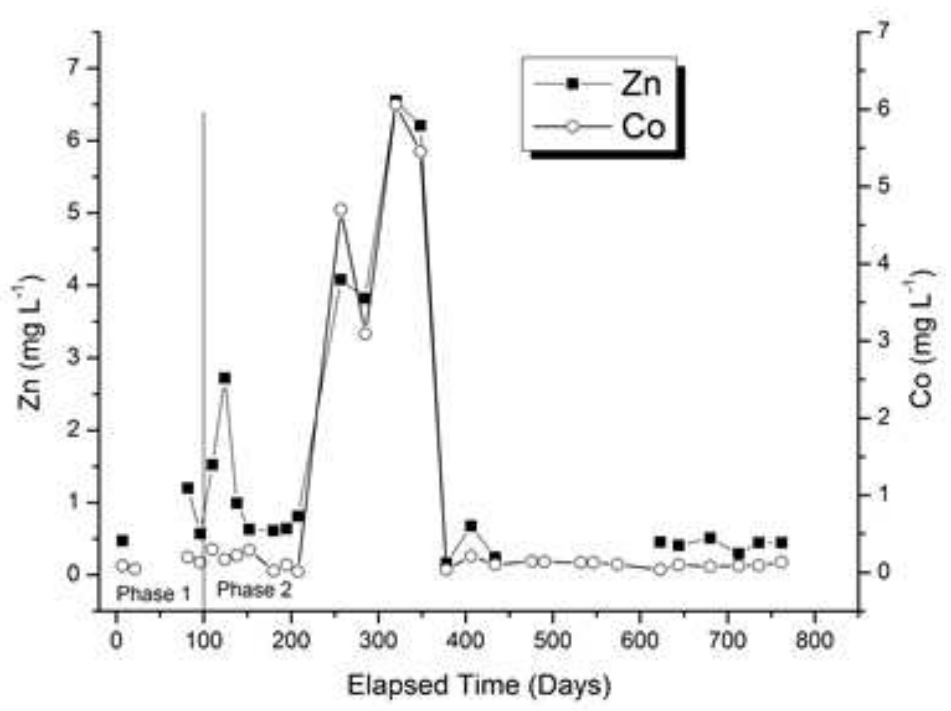

Fig. 9. $\mathrm{Zn}$ and Co concentration in the leachate of the experimental cell 


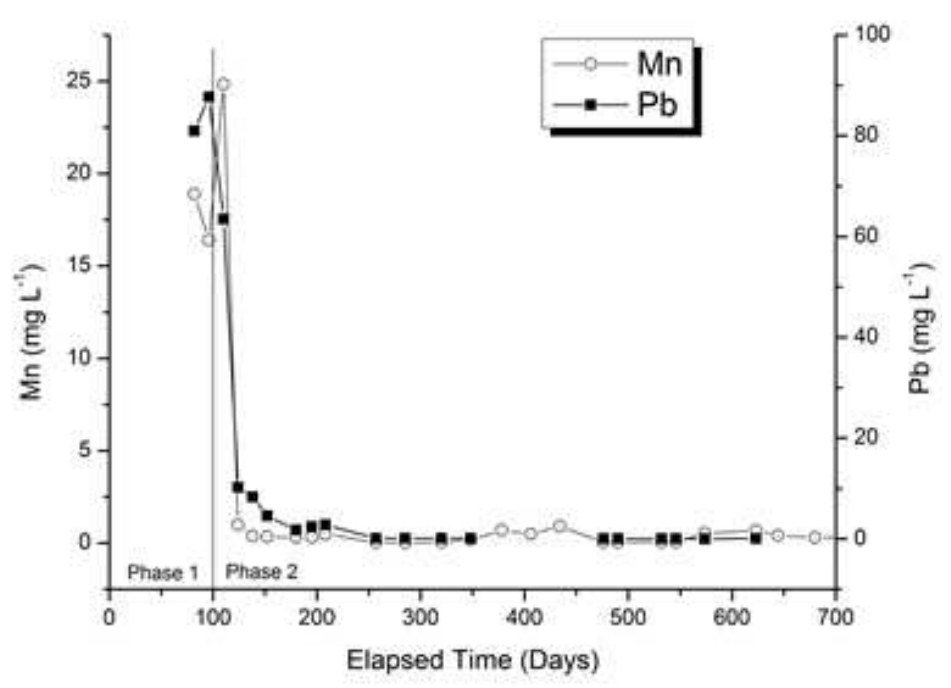

Fig. 10. $\mathrm{Mn}$ and $\mathrm{Pb}$ concentration in the leachate of the experimental cell

The lead $(\mathrm{Pb})$ and manganese $(\mathrm{Mn})$ showed high values in Stage 1 (Fig. 10). The average values were 3.14 and $14.6 \mathrm{mg} \mathrm{L}^{-1}$ for $\mathrm{Mn}$ and $\mathrm{Pb}$, respectively. These values are above MAV under Brazilian law: $1.0 \mathrm{mg} \mathrm{L}^{-1}$ $\mathrm{Mn}$ and $0.5 \mathrm{mg} \quad \mathrm{L}^{-1} \mathrm{~Pb}$ (Table 1). Maximum concentration of $\mathrm{Pb}$ and $\mathrm{Mn}$ were respectively 87.7 and $24.8 \mathrm{mg} \mathrm{L}^{-1}$ (Table 2). The high concentration of $\mathrm{Pb}$ in the leachate may be due to inadequate disposal of fluorescent lamps in the sanitary landfill. Besides $\mathrm{Pb}$, fluorescent lamps contain Hg. According to Santos et al. (2010), the masses of $\mathrm{Pb}$ and $\mathrm{Hg}$ per lamp present ranges of 0.07 to $0.75 \mathrm{mg}$ and 1.6 to $27.0 \mathrm{mg}$, respectively, in Brazil. The fluorescent lamps are considered hazardous materials in Brazil (ABNT, 2004). Another hypothesis for the $\mathrm{Pb}$ in leachate is an inadequate disposal of Cathode Ray Tubes (CRT) from television devices and computers, because CRT has a high concentration of $\mathrm{Pb}$ (Musson et al., 2000).

In the northern landfill of Porto Alegre city in southern Brazil, the leachate also presented high maximum concentration of Mn, $20.5 \mathrm{mg} \mathrm{L}^{-1}$ (Kuajara et al., 1997). The concentration of $\mathrm{Pb}, \mathrm{Hg}, \mathrm{Ni}$ and $\mathrm{Cd}$ in the leachate studied indicate that is important proper management of wastes such as batteries and fluorescent lamps in the City of Campinas. In addition, it is essential to establish a process of treatment of the leachate for the removal of ammonia nitrogen, organic matter and metals. In a real scale project to treat leachate from a sanitary landfill in southern Brazil, two anaerobic ponds (series anaerobic lagoons), activated sludge system and facultative ponds were performed and the overall efficiency for metal removal was $64 \%$ for zinc, $43 \%$ for lead, $35 \%$ for chromium and $31 \%$ for cadmium (Maia et al., 2012). However, this treatment system did not meet the release pattern and required further treatment.

\section{Conclusion}

Physicochemical analysis of the leachate generated from MSW confined in an isolated experimental cell built on the Delta A sanitary landfill in Campinas, southeastern Brazil, enabled to observe the early transition-approximately 100 days - from the acid anaerobic phase to the methanogenic phase of biodegradation of the MSW. This early transition period is not mentioned by the classic technoscientific literature i.e., 2 to 5 years; however, it is close to that found in research in tropical regions.

In Stage 1, which spanned the time from the cell being totally filled with MSW until the hundredth day of monitoring, a low $\mathrm{pH}$ along with high levels of Chemical Oxygen Demand (COD), Biochemical Oxygen Demand (BOD) and electrical conductivity were observed. In Stage 2, which spanned day 101 to day 945 , there was an increase in $\mathrm{pH}$ and a reduction in the COD and BOD.

There was an intense leaching of $\mathrm{Cd}, \mathrm{Fe}, \mathrm{Pb}, \mathrm{Mn}$ and $\mathrm{Ca}$ in Stage 1 and of $\mathrm{Co}, \mathrm{Zn}, \mathrm{Ni}$ and $\mathrm{Cu}$ in Stage 2. The heavy metal concentrations found in the leachate from the experimental cell were above the values allowed by Brazilian law.

\section{Acknowledgment}

The authors would like to thank FAPESP ("Fundação de Amparo à Pesquisa do Estado de São Paulo") for supporting the research (process number 2010/18560-4) and Consórcio TECAM Tecnologia Ambiental, Maccaferri do Brasil Ltda and the City Hall of Campinas for their support for conducting the research. The first author would like to thank CNPQ for scholarship doctoral. 


\section{Author's Contributions}

Jorge Luiz da Paixão Filho: Contributed to the design and conduct of experimental tests, data analysis and writing and review of the manuscript.

Miriam Gonçalves Miguel: Contributed to the design and conduct of experimental tests, data analysis and writing and review of the manuscript.

\section{Ethics}

We would declare that there is no conflict of interest among the authors.

\section{References}

ABNT, 2004. Associação brasileira de normas técnicas (ABNT). NBR 10004. Resíduos SólidosClassificação, ABNT.

Akgul, D., C.K. Aktan, K. Yapsakli and B. Mertoglu, 2013. Treatment of landfill leachate using UASGMBR-SHARON- Anammox configuration. Biodegradation, 24: 399-412. DOI: $10.1007 / \mathrm{s} 10532-012-9597-y$

Amor, C., E.D. Torres-Socías, J.A. Peres, M.I. Maldonado and I. Oller et al., 2015. Mature landfill leachate treatment by coagulation/flocculation combined with Fenton and solar photo-Fenton processes. J. Hazardous Mater., 286: 261-268.

DOI: 10.1016/J.JHAZMAT.2014.12.036

APHA, 1998. Standard methods for the examination of water and wastewater. American Public Health Association (APHA), American Water Works Association (AWWA), Water Environment Federation (WEF), Washington, D.C., USA.

Aziz, S.Q., H.A. Aziz, M.S. Yusoff, J.K. Bashir and M. Umar, 2010. Leachate characterization in semiaerobic and anaerobic sanitary landfills: A comparative study. J. Environ. Manage., 91: 2608-2614. DOI: $10.1016 /$ j.jenvman.2010.07.042

Benatti, J.C.B., J.L. Paixão Filho, M.A.G. Leme and M.G. Miguel, 2013. Construction of a large-scale experimental cell to obtain hydro-geomechanical parameters of MSW of the City of Campinas, Brazil. Proceedings of the 14th International Waste Management and Landfill Symposium, (MLS' 13), Cagliari, Italian, pp: 1-13.

Bilgini, M.S., A. Demir, M. Ince and B. Ozkaya, 2007. Metal concentrations of simulated aerobic and anaerobic pilot scale landfill reactors. J. Hazard. Mater., 145: 186-194.

DOI: 10.1016/j.jhazmat.2006.11.014

Bortolotto, T., J.B. Bertoldo, F.Z. Silveira, T.M. Defaveri and J. Silvano et al., 2009. Evaluation of the toxic and genotoxic potential of landfill leachates using bioassays. Environ. Toxicol. Pharmacol., 28: 288-293. DOI: 10.1016/j.etap.2009.05.007
Boumechhour, F., K. Rabah, C. Lamine and B.M. Said, 2013. Treatment of landfill leachate using Fenton process and coagulation. Water Environ. J., 27: 114-119. DOI: 10.1111/j.1747-6593.2012.00332.x

BRASIL, 2011. CONAMA. Resolução n. 430, de 13 de maio de 2011. Dispõe sobre as condições e padrões de lançamento de efluentes, complementa e altera a Resolução no 357, de 17 de marco de 2005, do CONAMA. Diário Oficial da União: República Federativa do Brasil, Poder Executivo, Brasília, DF, n. 92, 16 maio 2011. P: 89.

Brennan, R.B., E. Clifford, C. Devroedt, L. Morrison and M.G. Healy, 2017. Treatment of landfill leachate in municipal wastewater treatment plants and impacts on effluent ammonium concentrations. J. Environ. Manage., 188: 64-72. DOI: $10.1016 /$ j.jenvman.2016.11.055

Brennan, R.B., M.G. Healy, L. Morrison, S. Hynes and D. Norton et al., 2015. Management of landfill leachate: The legacy of European Union Directives. Waste Manage., 55: 355-63. DOI: 10.1016/j.wasman.2015.10.010

Budi, S., B.A. Suliasih, M.S. Othman, L.Y. Heng and S. Surif, 2016. Toxicity identification evaluation of landfill leachate using fish, prawn and seed plant. Waste Manage., 55: 231-237.

DOI: 10.1016/j.wasman.2015.09.022

CAMPINAS. In: WIKIPEDIA, a enciclopédia livre. Flórida: Wikimedia Foundation, 2015.

Cassano, D., A. Zapata, G. Brunetti, G. Del Moro and C. Di Iaconi et al., 2011. Comparison of several combined/integrated biological aop's setups for the treatment of municipal landfill leachate: Minimization of operating costs and effluent toxicity. Chem. Eng. J., 172: 250-257. DOI: 10.1016/j.cej.2011.05.098

Castrillón, L., Y. Fernández-Nava, M. Ulmanu, I. Anger and A. Marañón, 2010. Physico-chemical and biological treatment of MSW landfill leachate. Waste Manage., 30: 228-235. DOI: 10.1016/j.wasman.2009.09.013

Chen, P.H., 1996. Assessment of leachates from sanitary landfills: Impacts of age, rainfall and treatment. Environ. Int., 22: 225-237. DOI: 10.1016/0160-4120(96)00008-6

Dilallo, R. and O.E. Albertson 1961. Volatile acids by direct titration. Water Pollut. Control Federat., 33: 356-365.

Ehrig, H.J., 1983 Quality and quantity of sanitary landfill leachate. Waste Manage. Res., 1: 53-68. DOI: 10.1016/0734-242X(83)90024-1

Ehrig, H.J., 1989. Leachate Quality. In: Sanitary Landfilling: Process, Technology and Environmental Impact, Christensen, T.H., R. Cossu and R. Stegman (Eds.), Academic Press, London, pp: 213-230. 
Emenike, U.E., S.H. Fauziah and P. Agamuthu, 2012. Characterization and toxicological evaluation of leachate from closed sanitary landfill. Waste Manage. Res., 30: 888-897.

DOI: $10.1177 / 0734242 X 12443585$

Fan, H.J., H.Y. Shu, H.S. Yang and W.C. Chen, 2006. Characteristics of landfill leachates in central Taiwan. Sci. Total Environ., 361: 25-37. DOI: 10.1016/j.scitotenv.2005.09.033

Fauziah, S.H., C.U. Emenike and P. Agamuthu, 2013. Leachate risk of accumulated heavy metals in Pangasius sutchi. Waste Manage. Res., 31: 75-80. DOI: $10.1177 / 0734242 \mathrm{X} 13492840$

Gajski, G., V. Orescnin and V. Garaj-Vrhovac, 2012. Chemical composition and genotoxicity assessment of sanitary landfill leachate from Roving, Croatia. Ecotoxicol. Environ. Safety, 78: 253-259. DOI: 10.1016/j.ecoenv.2011.11.032

Hilles, A.H., S.S.A. Amr, R.A. Hussein, A.I. Arafa and O.D. El-Sebaie, 2015. Effect of persulfate and persulfate $/ \mathrm{H}_{2} \mathrm{O}_{2}$ on biodegradability of an anaerobic stabilized landfill leachate. Waste Manage., 44: 172-177. DOI: 10.1016/j.wasman.2015.07.046

IBGE, 2014. Instituto Brasileiro de Geografia e Estatística.

IBGE, 2010. Instituto Brasileiro de Geografia e Estatística. Pesquisa Nacional de Saneamento Básico. Rio de Janeiro. ISBN 978-85-240-4135-8 (meio impresso).

Jarup, L., 2003. Hazards of heavy metals contamination. Brit. Med. Bull., 68: 167-182.

Johansen, O.K. and D.A. Carlson, 1976. Characterization of sanitary landfill leachates. Water Res., 10: 1129-1134.

Kawai, M., I.F. Purwanti, N. Nagao, A. Slamet, J. Hermana and T. Toda, 2012. Seasonal variation in chemical properties and degradability by anaerobic digestion of landfill leachate at Benowo in Surabaya, Indonesia. J. Environ. Manage., 110: 267-275. DOI: 10.1016/j.jenvman.2012.06.022

Khattabi, H., L. Aleya and J. Mania, 2002. Changes in the quality of landfill leachates from recent and aged municipal solid waste. Waste Manage. Res., 20: 357-364.

Kjeldsen, P., M.A. Barlaz, A.P. Rooker, A. Baun and A. Ledin et al., 2002. Present and long-term composition of MSW landfill leachate: A review. Critical Rev. Environ. Sci. Technol., 32: 297-336.

Kochany, J. and E. Lipczynska-Kochany, 2009. Utilization of landfill leachate parameters for pretreatment by Fenton reaction and struvite precipitation-A comparative study. J. Hazardous Mater., 166: 248-254.

DOI: $10.1016 /$ j.jhazmat.2008.11.017
Kuajara, O., J.C.D. Sanchez, R.A. Ballestrim and E.C. Teixeira, 1997. Environmental monitoring of the north Porto Alegre Landfill, Brazil. Water Environ. Res., 69: 1170-1177.

Kulikowska, D. and E. Klimiuk, 2008. The effect of landfill age on municipal leachate composition. Bioresource Technol., 99: 5981-5985. DOI: 10.1016/j.biortech.2007.10.015

Kylefors, K., H. Ecke and A. Lagerkvist, 2003. Accuracy of COD test for landfill leachates. Water Air Soil Pollut., 146: 153-169.

DOI: $10.1023 / \mathrm{A}: 1023925508322$

Lo, I.M.C., 1996. Characteristics and treatment of leachates from domestic landfills. Environ. Int., 22: 433-442. DOI: 10.1016/0160-4120(96)00031-1

Maia, I.S., J.J.B. Restrepo, A.B. Castilhos Júnior and D. Franco, 2015. Evaluation of the biological treatment of landfill leachate Brazilian full-scale system. Engenharia Sanitária e Ambiental, 20: 665-675.

DOI: $10.1590 /$ S1413-41522015020040140926

Miguel, M.G., J.L. Paixão Filho, J.C.B. Benatti, M.A.G. Leme and B.C. Mortatti et al., 2016. Gravimetric composition of municipal solid waste disposed in a large-scale experimental cell in Southeastern Brazil. Int. J. Environ. Waste Manage., 17: 128-145. DOI: 10.1504/IJEWM.2016.076758

Mojiri, A., L. Ziyang, R.M. Tajuddin, H. Farraji and N. Alifar, 2016. Co-treatment of landfill leachate and municipal wastewater using the ZELIAC/zeolite constructed wetland system. J. Environ. Manage., 166: 124-130. DOI: $10.1016 /$ j.jenvman.2015.10.020

Muller, G.T., A. Giacobbo, E.A.S. Chiaramonte, M.A.S. Rodrigues and A. Meneguzzi et al., 2015. The effect of sanitary landfill leachate aging on the biological treatment and assessment of photoelectrooxidation as a pre-treatment process. Waste Manage., 36: 177-183. DOI: 10.1016/j.wasman.2014.10.024

Musson, S.E., Y.C. Jang, T.G. Townsend and I.H. Chung, 2000. Characterization of lead leachability from cathode ray tubes using the toxicity characteristic leaching procedure. Environ. Sci. Technol., 34: 4376-4381. DOI: 10.1021/es0009020

Oulego, P., S. Collado, A. Laca and M. Díaz, 2016. Impact of leachate composition on the advanced oxidation treatment. Water Res., 88: 389-402. DOI: $10.1016 /$ j.watres.2015.09.048

Qasin, S.R. and W. Chiang, 1994. Sanitary landfill leachate: Generation, control and treatment. Technomic publishing, Lancaster. 
Rafizul, I.M. and M. Alamgir, 2012. Characterization and tropical seasonal variation of leachate: Results from landfill lysimeter studied. Waste Manage., 32: 2080-2095.

DOI: 10.1016/j.wasman.2012.01.020

Renou, S., J.G. Givaudan, S. Poulain, F. Dirassouyan and P. Moulin, 2008. Landfill leachate treatment: Review and opportunity. J. Hazardous Mater., 150: 468-493. DOI: 10.1016/j.jhazmat.2007.09.077

Ripley, L.E., W.C. Boyle and J.C. Converse 1986. Improved alkalimetric monitoring for anaerobic digestion of high-strength wastes. Water Pollut. Control Federat., 58: 406-411.

Santos, E.J.D., A.B. Hermann, F. Vieira, C.S. Sato and Q.B. Corrêa et al., 2010. Determination of $\mathrm{Hg}$ and $\mathrm{Pb}$ in compact fluorescent lamp by slurry sampling inductively coupled plasma optical emission spectrometry. Microchemical, 96: 27-31. DOI: $10.1016 /$ j.microc.2010.01.012

Schiopu, A.M. and M. Gavrilescu, 2010. Options for the treatment and management of municipal landfill leachate: Common and specific issues. Clean Soil Air Water, 38: 1101-1110. DOI: $10.1002 /$ clen.200900184

Silva, A.C., M. Dezotti and G.L. Sant'anna Júnior, 2004. Treatment and detoxification of a sanitary landfill leachate. Chemosphere, 55: 207-214.

DOI: 10.1016/j.chemosphere.2003.10.013
Tatsi, A.A. and A.I.A. Zouboulis, 2002. A field investigation of the quantity and quality of leachate from a municipal solid waste landfill in Mediterranean climate (Thessaloniki, Greece). Adv. Environ. Res., 6: 207-219. DOI: $10.1016 / \mathrm{S} 1093-0191(01) 00052-1$

Tsarpali, V., M. Kamilari and S. Dailianis, 2012. Seasonal alterations of landfill leachate composition and toxic potency in semi-arid regions. J. Hazardous Mater., 233-234: 163-171.

DOI: 10.1016/j.jhazmat.2012.07.007

Youcai, Z., W. Luochun, H. Renhua, X. Dimin and G. Guowei, 2002. A comparison of refuse attenuation in laboratory and field scale lysimeters. Waste Manage., 22: 29-35. DOI: $10.1016 / \mathrm{S} 0956-053 \mathrm{X}(01) 00028-9$

Zhang, Q.Q., B.H. Tian, X. Zhang, A. Ghulam and C.R. Fang et al., 2013. Investigation on characteristics of leachate and concentrated leachate in three landfill leachate treatment plants. Waste Manage., 33: 2277-2286.

DOI: 10.1016/j.wasman.2013.07.021 